\title{
Topics in social and health informatics research
}

This number of the Finnish Journal of eHealth and eWelfare include a representative and timely sample of research and development results in social and health informatics context. The focus of interest in most of the research is introducing or developing new customeroriented digital services. The main actors in the studies are citizens (customers/patients) and social and health care professionals. The main goal is developing and improving social and health care functions.

Previously information regarding customer satisfaction has been gathered from patients. Customer satisfaction data has been used to evaluate the quality of care from the viewpoint of adult patients. As a new perspective two of the articles consider gathering patient experiences from child patients and their parents to improve health care functions.

Articles associated with the national information system services like client data archive in social welfare services or My Kanta pages contain evaluation the quality of client document structures, the transfer of information between My Kanta service and the regional online services and solutions on acting on behalf of someone. Furthermore, users are increasingly in need of information from databases of many different providers. One article introduces a user-oriented prototype combine information from different sources and to get an overall picture of the situation of the customer to herself/himself and to the professional.

New technologies for nursing practices and extraction of information are also presented in the articles. In nursing practices the topics are monitoring of body temperature and infusion treatments, using video conferences or cognitive services and tracking personnel. While designing new digital services, business and security of using the services cannot be forgotten. Users must be able to trust the information systems and information security must be observed while storing, transferring and using the information. Information cannot be lost and digital services cannot be a target for denial of service attack. Furthermore, the services should fulfill the needs of the users of multiprofessional health care. For the services to be used the suppliers should develop their services to be userfriendly. One article introduces a conceptual model for business ecosystem for connected health by mapping service needs for healthcare in the future

The know-how and education of health care professionals regarding the introduction of new kinds of digital services is also a current topic. It should be known what kind of competency is needed in the future and therefore what kind of education is required.

The key note presentations of Research Days are: SOTE:n kyberturvallisuus, Perttu Halonen, tietoturvaasiantuntija, Viestintäviraston Kyberturvallisuuskeskus and Developing Health IT Workforce Skills and Empowering Women to Take on Greater Roles in Today's Health Informatics Landscape, Rachelle Blake, project coordinator, EU-US eHealth work; CEO, Omni Micro / Omni Med Solutions $\mathrm{GmbH}$

The evaluation process for the Research Days and the Journal was conducted using the double-blind method. Each submission received feedback in the reviewers' own words and ratings in 11 categories from at least two reviewers. Based on the ratings, three papers were reviewed by two more reviewers. The best paper was thus selected based on ratings from four reviewers.

The editor gratefully acknowledges the efforts of Sirpa Kuusisto-Niemi, Maija Valta, Paula Lehto, Tiina Kortteisto, Johanna Kaipio, Heljä Lundgren-Laine, Marita Koivunen, Virpi Hotti, Irmeli Luukkonen, Pekka Ruotsalainen, Pirkko Nykänen, Kari Harno, Hannele Hyppönen, Elina Rajalahti, Reetta Raitoharju, Virpi Jylhä and Teija Norri-Sederholm, who acted as reviewers. Juha Mykkänen and Ulla-Mari Kinnunen were involved in selecting the best paper.

\section{Kristiina Häyrinen \\ Editor-in-Charge}

